\title{
SOME POSSIBILITIES OF STUDYING THE PRECISION FARMING IN ESTONIA, METHODS AND RESULTS OF COMPLEX INVESTIGATION
}

\author{
Võsa, T. ${ }^{1}$, Nugis, E. ${ }^{1}$, Vennik, K. ${ }^{2}$, Meripõld, H. ${ }^{1}$, Viil, P. ${ }^{1}$, Kuht, J. ${ }^{3}$ \\ ${ }^{1}$ Estonian Research Institute of Agriculture, Teaduse 13, Saku 75501, Estonia \\ ${ }^{2}$ Tartu University, Faculty of Science and Technology, Vanemuise 46, Tartu 50090 \\ ${ }^{3}$ Estonian University of Life Sciences, Kreutzwaldi 1, Tartu 51014 taavi.vosa@eria.ee
}

Abstract: It is a fact that crops growth conditions vary greatly in the same field. Provisionally actual growth conditions are made up of many components, i.e. variation of natural conditions (climate $\&$ soil), results of effect of machinery on soil ( soil compaction) and unfavourable conditions for plant growing. In Estonia rather widely used ATV are causing remarkable damage to landscapes.

All collected data were georeferenced by means of a GPS-receiver and postprocessed for position correction. For ATV damages assessment the trajectory was recorded. On damaged sites both area and form of damage were assessed. The collected data were compared to the digital soil map.

Economic loss on the average, due to unfavourable conditions for plants growth in the case of winter rye "Portal" was 131 euros per ha, for Melilotus 18.5 euros per ha and for spring barley "Anni" 1000 euros per ha.

Key words: GPS, soil, yield, ATV, penetrometer, rye, melilotus

\section{INTRODUCTION}

Previous studies have proved the efficiency of the GPS-based precision farming as regarding the quality of the final product and protection of environment and its applicability in intensive agricultural production. A number of positive examples can be given such as: Backes, M. and Plümer, L. (2003), Kim, Y. and Reid, J.F. (2003), Shibusawa, S. (2003). As far as Estonia is concerned, search of possibilities of application of precision

Please use the following format when citing this chapter:

Võsa, T., Nugis, E., Vennik, K., Meripõld, H., Viil, P. and Kuht, J., 2009, in IFIP International Federation for Information Processing, Volume 293, Computer and Computing Technologies in Agriculture II, Volume 1, eds. D. Li, Z. Chunjiang, (Boston: Springer), pp. 1-7. 
farming has been under way since 1999. By now, GPS-receivers accuracy for both position and area measurements has been studied. Six receivers are compared and results declared, that although position accuracy for GPS receivers is not remarkably good, area measurement errors are acceptably low even on non-corrected GPS-receivers, compared to traditional measurement methods. Therefore, a GPS-receiver is suitable for area measurement through its robustness, ease of use and fast results.

We have relevant positioning experience as a result of use of a satellite navigator, still, through the years, our main problem has been the diversity of soils. So a question arises: how large a soilscape unit will be for to plausibly determine such a diversity and appreciate the factors influencing the final yield of crops. It appeared that even in the USA with its very large fields the authors Q.E. Larson and P.C. Robert point out as an example of Minnesota (Larson and Robert, 1991) that when soil maps are overlaid by landscape maps, the soilscape becomes extremely large. It is not feasible to manage each soilscape unit as separate field with conventional practices. The size of a soilscape unit may vary from one hectare to many hectares. As Estonian fields are many times smaller, we limited ourselves to many times smaller soilscape units. It differs in the case of a particular field. We have not left aside experimental patches where in co-operation with PhD Agr. Peeter Viil the said experimental patches were compacted with tractor MTZ-82. In this case the size of experimental patches was $12.5 \mathrm{~m}^{2}$ (Nugis et al, 2004, 11-14). Even on such a small area it is possible to specify the variability of the physical state of soil. It is one thing when we affect the soil deliberately and artificially, the other thing is if it occurs at random. Extremely negative factors may occur in the field incidentally and specifying of these by means of a navigator is of considerable importance. At the same time another approach is possible by trying to model bioproductivity taking into account the soils climatic conditions in extreme sites. The author of this conception is Professor Heino Tooming and it is being developed by PhD. Biolog. Jüri Kadaja. To be brief, these ideas have been reflected in a number of publications. Connected with the topic of this particular work is the source: Nugis, E., Kadaja, J., Vösa, T. (2003).

Still, Estonia is halfway towards the level that has been achieved in developed countries nowadays. Despite of this, in our research work we have set wide-range objectives. Thus, the main objectives of our research workers are to investigate the possibilities of increasing the efficiency of agricultural machines and the respective technologies in Estonian soil and climatic conditions. To this end we have tried:

- $\quad$ to study the soil physical properties by using of tramlines system;

- $\quad$ to discover new methods (results of complex investigations related to GPS technologies) for improving and stabilizing the quality of the yield and preservation of environmental ability;

- $\quad$ to study new ways of effective trafficability. 
Through this project related to the GPS technology, we have tried to find:

- some new possibilities of providing favourable soil physical properties and their adequate assessment;

- $\quad$ results of crop production after several damages;

- dynamics between appropriate indices of soil compaction and crop yield.

This work has been accomplished within the framework of the grant work No. 6888 of the Scientific Foundation and its duration is four years beginning from the year 2006 .

\section{MATERIALS AND METHODS}

Soil units, study sites, co-authors/author of experiments are as follows:

Fragi-Stagnic Albeluvisol (sandy loam), Haage Agro Ltd., quite near Tartu, N58 $22^{\prime}$ and E26 $6^{\circ} 7^{\prime}$ (tramlines and winter rye "Portal"), co-authors of field experiments: Mr. Andres Härm, Dr. Hab. Eng. Edvin Nugis, PhD Jaan Kuht, MSc. Geogr. Kersti Vennik;

- Enti-Umbric Podzol (loamy sand), landscape, recreation centre Andu Ltd. quite near Otepää, N58 $04^{\prime}$ and E26 ${ }^{\circ} 26^{\prime}$, special highway for ATV (All Terrain Vehicle), co-author of experiments MSc.Geogr. Kersti Vennik;

- Endoeutri-Mollic Cambisol (sandy loam), field with chosen random deep tracks after the application liquid organic manures Juuliku piggery, Saku Community, quite near Tallinn, N59 ${ }^{\circ} 8^{\prime}$ and E24 $36^{\prime}$ (after that sowing the spring barley "Julia"), co-authors of field experiments Dr. Hab. Eng. Edvin Nugis and PhD-student Taavi Võsa;

Calcari- Eutric- Cambisol (sandy loam), experimental field of Agricultural Research Centre (PMK), N 58 $58^{\prime}$ and E 24 $43^{\prime}$, Kuusiku, quite near Rapla (Melilotus) co-author of field experiments MSc. Agr. Heli Meripõld.

- $\quad$ According to our scientific research programme we have organized both field and field-laboratory experiments. We set our targets:

- to achieve stable quality of yield sustainable also to the appliance for the EU Standard;

- $\quad$ to test new pioneer cultures decreasing this way vulnerability to soil compaction.

Most of our investigations were carried out by using GPS receiver Trimble GeoExplorer 3 for specifying the co-ordinates of soil samples and the damaged areas in the field. For GIS data management and primary analysis, computer programme Pathfinder Office 2.80 (Trimble Inc.) was 
used. Further data analysis was carried out by means of Microsoft Excel 2003.

We have also used some experiments for measuring the soil physical properties in several soil layers: penetrometer MOBITECH for registration of cone resistance, Eijkelkamp's ring kits $\left(100 \mathrm{~cm}^{3}\right)$ for measuring soil bulk density and percometer for measuring soil volumetric moisture content through dielectric conductivity and permittivity, respectively. Crop yield was measured by ordinary weighing with a weighbridge in the case of rye and by means of tests weights in the case of melilotus.

\section{RESULTS AND DISCUSSION}

\section{Crop damages}

As can be seen in Fig. 1 and Table 1, there are significant damages on winter rye canopy. These areas are not producing grain although they have got their amount of fertilizers, pesticides, seeds, soil tillage and seeding work. Thus, expenses have been made but no yield harvested. This is neither economically nor ecologically desired result. Calculations show that in this field from 94 to 163 euros get lost due to winter damages. It is not clear yet whether all these damages are soil-originated because the winter of 2006 was very cold and snowless and, consequently, plants suffered a lot.

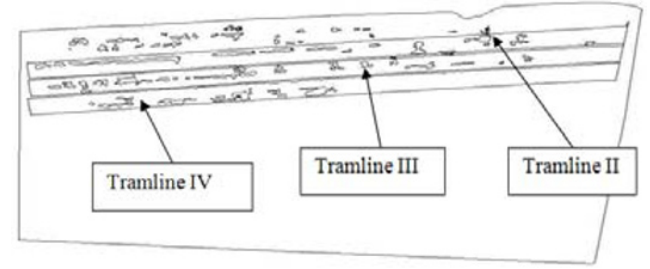

Fig. 1. An excerpt from field map with crop damage areas and tramlines in the field of "Peedimäe", Haage Agro Ltd.

Table 1. Results of the observation made by means of GPS-receiver GeoExplorer 3 of winter damages of the winter rye in the field "Peedimäe" (Haage Agro Ltd.)

\begin{tabular}{lcccccc}
\hline $\begin{array}{l}\text { Number of } \\
\text { tramline }\end{array}$ & $\begin{array}{c}\text { Area per } \\
\text { tramline, ha }\end{array}$ & $\begin{array}{c}\text { Yield } \\
\mathrm{t} \mathrm{ha}^{-1}\end{array}$ & \multicolumn{3}{c}{ Damages, i.e. empty crop area } & Lost income \\
\cline { 5 - 7 } & 1.36 & 4.6 & 0.01 & 1216 & 8.9 & 163 \\
II & 1.32 & 4.6 & 0.01 & 1015 & 7.7 & 136 \\
III & 1.37 & 4.7 & 0.007 & 730 & 5.1 & 98 \\
IV & 1.35 & 0.96 & 0.009 & 978 & 7.2 & 131 \\
Average & & & &
\end{tabular}

As can be seen from the Table 1, thanks to GPS receiver it became possible to determine on a large scale the damages caused due to 
unfavourable winter conditions, i.e. empty crop area where nothing but weeds grew. Crop yield that was assessed in the range of each tramline separately, varied greatly because of empty areas, which, as a matter of fact, is the result of differences in growing conditions of the winter rye "Portal". The latter exerts a substantial effect on the quality of crop yield.

A similar economical loss can be calculated in the case of melilotus. Observed field had suffered noticeable damages, zero melilotus plant areas making up in total of $285 \mathrm{~m}^{-2}$. The measured yield from this field was $145 \mathrm{~kg}$ seeds per ha ${ }^{-1}$ and the seed price on calculations was 4.5 euros. Consequently, damaged areas of fields reduced the income from the field by 18.5 euros per $\mathrm{ha}^{-1}$.

Both cases serve as examples of heterogeneity of actual fields as compared to good farms. A much worse picture can be observed on the farms with lower agronomical culture of soil tillage and incorrect input management.

\section{Soil Erosion and Trafficability}

We applied the same principles in completely different domain, i.e. in assessing erosion-hazardous sites of soil. The ATV track (highway) under observation was passed together with a GeoExplorer in operation and the map below was obtained (Fig. 2).

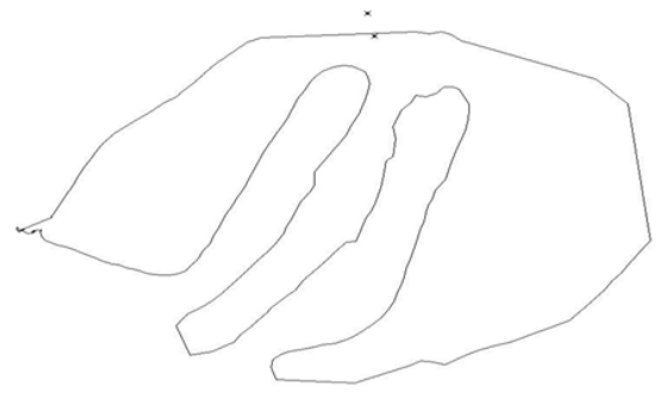

Fig. 2. Example of outline of a special highway for ATV, N58 $04^{\prime}$ and E26 $26^{\prime}$

In this map crosses mark the soil sample co-ordinates where the abovementioned instrumental investigations of soil physical properties where carried out and which can be seen in Fig. 3 below.

There can be observed two erosion-hazardous places which are marked by rings in Fig. 3. The signs of erosion hazard were in their initial stadium. This situation is hazardous because it may turn into an irreversible process in the case of a long period of heavy rains. At the present stage, this is to illustrate the particularity of our approach. 


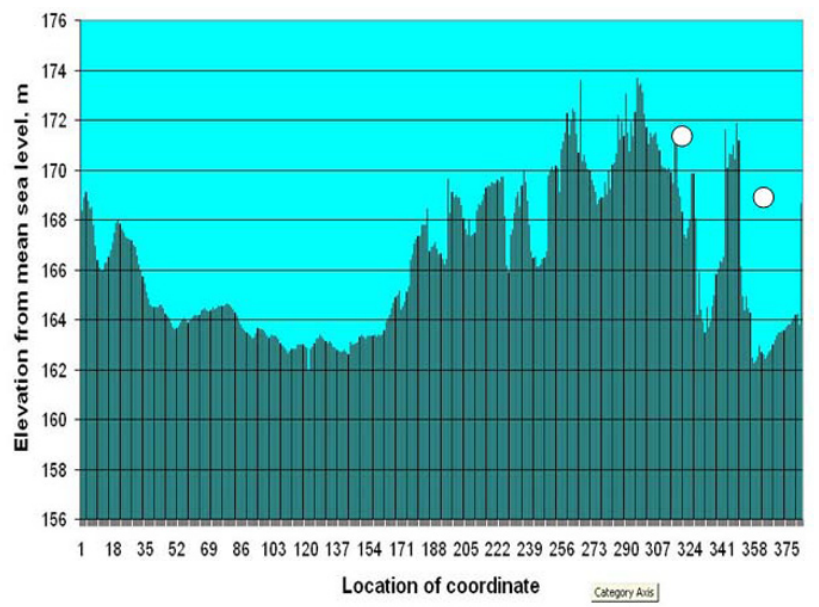

Fig. 3. Changes in the altitude from MSL on the highway for ATV

Table 2. The aftereffect of repeated compaction of soil in Juuliku experiments in 2002

\begin{tabular}{lcccccc}
\hline $\begin{array}{l}\text { Variant of } \\
\text { experiment }\end{array}$ & $\begin{array}{c}\text { Co-ordinates of } \\
\text { the object }\end{array}$ & $\begin{array}{c}\text { Covered } \\
\text { with } \\
\text { cultured } \\
\text { plants, \% }\end{array}$ & $\begin{array}{c}\text { Penetration } \\
\text { resistance, N } \\
\text { cm }^{-2}\end{array}$ & $\begin{array}{c}\text { Moisture } \\
\text { content, \% } \\
\left(\mathrm{w} \mathrm{w} \mathrm{w}^{-1}\right)\end{array}$ & $\begin{array}{c}\text { Yield, } \\
\text { tha }^{-1}\end{array}$ & $\begin{array}{c}\text { Lost } \\
\text { income *) } \\
€\end{array}$ \\
\hline $\begin{array}{l}\text { Checked, not } \\
\text { compacted }\end{array}$ & $\begin{array}{r}\mathrm{N} 59^{\circ} 18^{\prime} 444^{\prime \prime} \\
\mathrm{E} 24^{\circ} 36^{\prime} 47^{\prime \prime}\end{array}$ & 90 & 288 & 20.6 & 2.1 & 734 \\
Fresh track & $\begin{array}{r}\mathrm{N}^{\circ} 9^{\circ} 18^{\prime} 44.3^{\prime \prime} \\
\mathrm{E} 24^{\circ} 36^{\prime} 46.2^{\prime \prime}\end{array}$ & 10 & 322 & 18.9 & 0.4 & 1164 \\
Old track & $\begin{array}{r}\mathrm{N} 59^{\circ} 18^{\prime} 44.2^{\prime \prime} \\
\mathrm{E} 24^{\circ} 36^{\prime} 46^{\prime \prime}\end{array}$ & 50 & 311 & 19.9 & 1.3 & 936 \\
\hline
\end{tabular}

Note: if the yield is 5 that (many years mean)

We are to face a rather serious situation when considering the situation of a field where both consequences and protection of environment are ignored. For this purpose we had chosen a field in the phase of sprouting of spring barley "Anni". The field had suffered of extreme trafficability and winter swine sludge in large amounts was poured via a hose of a truck tank onto it. In spring a sad sight could be seen where in the field there were deep tracks with maximum depth up to $33 \mathrm{~cm}$. Still, in the field untouched places could be found (calculated area $12.5 \mathrm{~m}^{2}$ ) and old tracks left from autumn which were also taken under observation. For the results see Table 2.

Our opinion is: no comments.

\section{CONCLUSIONS}

As result of the complex investigations and obtaining the relevant information it enabled the growers to produce high quality cereals in 
different soil and climatic conditions of Estonia and, consequently, to get higher incomes. A data bank (accessible and stable in functioning) of quality indicators for most widespread cereals varieties and suitable digital maps will be produced. Probably by these innovative investigations it will be possible to improve the agricultural sector thanks to patentable inventions and corresponding implementation. Probably, it will be possible to cover very important to Estonia topic areas, GIS , GPS, and precision farming. In conclusion, it can also be pointed out that the methodology worked out by us where the main attention is paid to substantial deviations cropped up in the course of soil tillage and in entertainment sector. These deviations can be specified by means of modern GPS-receivers and assessed in complex. Lost income speaks for itself and gives a reason to a farmer as well as to an economist to re-estimate soil tillage strategies and to exclude risks.

\section{REFERENCES}

Backes, M. And Plümer, L. 2003. Use of geographic information systems to evaluate the plausibility of weed maps. Proceedings of the 4th European Conference on Precision Agriculture and 1st European Conference on Precision Livestock Farming. Programme book of joint conference of ECPA - ECPLF (Eds. A.Werner, A Jarfe), 355-356.

Kim, Y. and Reid, J.F. 2003. Software development for vision-based crop remote sensing. Proceedings of the 4th European Conference on Precision Agriculture and 1st European Conference on Precision Livestock Farming. Programme book of joint conference of ECPA - ECPLF (Eds. A.Werner, A Jarfe), 461-462.

Larson, W.E. and Robert, P.C.1991. Farming by soil. Papers from a workshop on Soil Management for Sustainability (Eds. R. Lal and F.J. Pierce) in Edmonton, Alberta, Aug. 1989 (ISBN 0-935734-23-6), 103-112.

Nugis, E., Kadaja, J., Võsa, T. 2003. Precision farming Management in Estonia (Estland). Supplement of the Proceedings of the 4th European Conference on Precision Agriculture of ECPA - ESPLF, June 15 - 18, 1-18

Nugis, E., Kuht, J., Viil, P., Müüripeal, M. 2004. How to prevent negative influence of machine technologies on soil?. Annual Report of ESF grant No 4801 (ISBN 9949-10-8527), Saku: SCA Ecofiller ${ }^{\circledR} \&$ Estonian Branch of ISTRO, 165 p (in Estonian).

Shibusawa, S. 2003. Precision farming Japan model for small farm agriculture. Proceedings of the 4th European Conference on Precision Agriculture and 1st European Conference on Precision Livestock Farming. Programme book of joint conference of ECPA - ECPLF (Eds. A.Werner, A Jarfe), 571-572. 